\title{
Pengembangan Poster Kesehatan Reproduksi Berbasis Pendidikan Karakter Menggunakan Canva pada Usia Remaja Sekolah di SMA
}

\author{
${ }^{1 *}$ Ervan Johan Wicaksana, ${ }^{2}$ Pramana Atmadja, ${ }^{1}$ Yuli Asmira \\ 1Program Studi Pendidikan Biologi, Universitas Jambi, Jl. Lintas Jambi-Muara Bulian No. Km. 15, Jambi \\ 36122 Indonesia \\ 2Program Studi Pendidikan Bahasa Inggris, Universitas PGRI Madiun, Jl. Setia Budi No. 85 Madiun, \\ Jawa Timur, 63118 Indonesia \\ *Corresponding Author e-mail: ervan_jw@unja.ac.id
}

Received: June 2020; Revised: June 2020; Published: July 2020

\begin{abstract}
Abstrak
Penelitian ini bertujuan untuk mengembangkan poster kesehatan reproduksi berbasis pendidikan karakter menggunakan canva pada usia remaja sekolah di SMA. Penelitian ini merupakan penelitian analisis-deskriptif dengan metode kuantitatif yang dilakukan di SMA Negeri 8 Kota Jambi. Produk divalidasi oleh ahli materi dan ahli media menggunakan lembar validasi, yang selanjutnya diujicoba pada kelompok kecil (6 siswa) dan kelompok besar (30 siswa dan 1 guru) menggunakan instrumen berbentuk angket untuk mendapatkan persepsi siswa dan guru. Keefektifan produk juga diuji menggunakan instrumen tes degan desain One group pretest-posttest. Hasil penelitian menunjukkan bahwa (1) validasi oleh ahli materi $(93,3 \%)$ dan ahli media $(87,5 \%)$ berkategori sangat baik, (2) ujicoba pada 6 orang kelompok kecil $(81,4 \%)$, kelompok besar $(87,3 \%)$ dan guru $(83,3 \%)$ diperoleh tanggapan dengan kategori sangat baik, dan (3) hasil belajar siswa meningkat dengan kategori sedang $(0,65)$. Berdasarkan hasil penelitian dapat disimpulkan bahwa poster kesehatan reproduksi berbasis pendidikan karakter menggunakan canva layak digunakan dalam pembelajaran.
\end{abstract}

Kata Kunci: Poster, Kesehatan Reproduksi, Usia Remaja Sekolah

\section{The Development of Reproductive Health Poster Based on Character Education Using Canva in School Adolescents}

\begin{abstract}
This study aimed to develop a reproductive health poster based on character education using Canva in the school's teenage years in high school. This research is a descriptive analysis research with quantitative methods conducted at SMA Negeri 8 Jambi City. The product was validated by material experts and media experts using validation sheets, which were then tested on small groups (6 students) and large groups (30 students and 1 teacher) using questionnaire-shaped instruments to get students and teacher perceptions. The effectiveness of the product was also tested using a test instrument with the One group pretest-posttest design. The results showed that (1) validation by material experts (93.3\%) and media experts (87.5\%) were categorized as very good, (2) trials in 6 small groups $(81.4 \%)$, large groups $(87,3 \%)$ and teachers $(83.3 \%)$ obtained responses in the excellent category, and (3) student learning outcomes improved in the moderate category (0.65). Based on the results of the study it can be concluded that the reproductive health poster based on character education using canva is suitable for use in learning.
\end{abstract}

Keywords: Poster, Reproductive Health, School Adolescence

How to Cite: Wicaksana, E., Atmadja, P., \& Asmira, Y. (2020). Pengembangan Poster Kesehatan Reproduksi Berbasis Pendidikan Karakter Menggunakan Canva pada Usia Remaja Sekolah di SMA. Jurnal Penelitian dan Pengkajian Ilmu Pendidikan: e-Saintika, 4(2), 160-172. doi:https://doi.org/10.36312/e-saintika.v4i2.215 


\section{PENDAHULUAN}

Kesehatan reproduksi remaja merupakan suatu keadaan sehat yang berkaitan dengan sistem organ, fungsi dan proses reproduksi yang terjadi pada remaja yang tidak hanya terbebas dari penyakit dan kecacatan, namun juga sehat secara mental, sosial dan budaya (Efendi \& Makhfudli, 2009). Informasi mengenai kesehatan reproduksi sangat penting dikatehui oleh remaja, agar remaja menerima informasi yang benar mengenai kesehatan reproduksi. Salah satu cara remaja mendapatkan informasi yang tepat tentang kesehatan dengan belajar dengan menyisipkan pendidikan karakter dimaterinya. Sehingganya materi tentang kesehatan reproduksi dapat masuk secara implisit dalam pendidikan.

Perkembangan pada masa remaja mengakibatkan kondisi yang membingungkan, menciptakan keraguan, ketakutan dan kecemasan karena pada masa ini merupakan masa yang paling banyak mengalami perubahan secara psikologis, biologis dan fisologis (Hartini, 2017). Kebingungan-kebingungan yang dihadapi pada tahap perkembangan remaja tidak jarang mengakibatkan permasalahan pada diri remaja itu sendiri, orang tua dan lingkungannya. Salah satu masalah yang sering dihadapi oleh remaja adalah kurangnya informasi mengenai kesehatan reproduksi remaja.

Usia remaja memunginkan untuk mengakses berbagai macam informasi termasuk yang menyajikan adegan seksual secara implisit. media yang ada, baik media elektronik, ataupun media cetak contohnya, sering kali menyuguhkan sajiansajian yang terlalu dini ataupun tidak layak bagi remaja. Media sosial mengajak siapa saja yang tertarik untuk berpartisipasi dengan memberi kontribusi dan feedback secara terbuka, memberi komentar, serta membagi informasi dalam waktu yang cepat dan tak terbatas (Wahyuningtias \& Wibisono, 2018).

Usaha untuk mencegah perilaku seksual akibat pengaruh media sosial ialah peranan orang tua dan kekuatan agama seseorang menjadi pokok utama. Kedua hal tersebut merupakan pondasi utama mencegah terjadinya seks bebas. Adapun peran orang tua yakni selalu memberi didikan yang baik sesuai umur, sebagai teman yang baik, serta memilih lingkungan yang mendorong anak melakukan hal-hal postif seperti mengaji, sekolah, olahraga. Menurut Novendra dan Puspitasari (2017), cara agar terhindar dari perilaku seksual dari media sosial ialah senantiasa meningkatkan pengendalian diri, lebih terbuka dengan orang tua, kerabat, guru.

Menurut Hasanah (2016) menjaga kebersihan organ reproduksi dapat dilakukan dengan cara (1) menjaga kesehatan vagina dimulai dari memperhatikan kebersihan diri. Indonesia merupakan daerah yang beriklim tropis. Udara panas dan cendrung lembap sering memproduksi banyak keringat. Terutama dibagian tubuh yang tertutup dan lipatan-lipatan kulit, seperti daerah alat kelamin. Kondisi ini menyebabkan mikroorganisme jahat, terutama jamur mudah berkembang biak, yang akhirnya bisa menimbulkan infeksi; (2) mengganti celana dalam minimal dua kali dalam sehari; (3) membersihkan kotoran yang keluar dari alat kelamin atau anus dengan menggunakan air bersih atau kertas pembersih (tisu); (4) gerakan cara membersikan alat kelamin adalah dari arah vagina kearah anus, untuk mencegah kotoran anus masuk ke vagina; (5) tidak menggunakan air yang kotor untuk membersihakan vagina; (6) dianjurkan untuk mencukur atau merapikan rambut kamaluan karena bisa ditumbuhi jamur atau kutu yang dapat menimbulkan rasa gatal dan tidak nyaman; dan (7) pada siklus menstruasi, remaja perempuan mengganti pembalut setiap tiga hingga empat jam sekali.

Menurut Irianto (2015), adapun usaha untuk menghindari perilaku 
menyimpang yaitu (1) sebagai seorang remaja, maka sangat diperlukan keimanan yang kuat sehingga mampu membentengi diri dari perilaku seks bebas; (2) membatasi pergaulan antara remaja pria dan wanita agar tidak terlalu bebas; (3) membuat regulasi (peraturan) yang melarang ditampilkannya atau ditayangkannya acara tontonan yang berbau pornografi dan porno aksi; dan (4) menambah kegiatan yang positif di luar sekolah, misalnya kegiatan olahraga.

Menurut Wicaksana et al. (2015) lulusan Sekolah Menengah Atas (SMA) kurang terampil dalam menerapkan ilmu yang didapatkan disekolah untuk memecahkan masalah dikehidupan sehari-hari. Pendidikan seakan mencabut peserta didik dari lingkungan, sehingga menjadi asing di lingkungannya sendiri. Hal ini dikhawatirkan akan berdampak pada perilaku menyimpang khususnya tentang kesehatan reproduksinya, terlebih lagi orang tua masih menganggap terlalu tabu untuk membicarakan masalah kesehatan reproduksi pada anak remajanya. Sehingga orang tua cendrung melimpahkan semua pendidikan dan informasi yang benar hanya didapatkan dan dipelajari hanya dengan sekolah.

Menurut penelitian Ekawati, Saputra, dan Periantalo (2016) perilaku seksual siswa-siswi di Kota Jambi sangat memprihatinkan. Hal ini diketahui dari 518 responden SMA, SMP dan SMK sebanyak 77,22\% pernah berpacaran. Berawal dari berpacaran yang menjadikan siswa-siswi merujuk pada penyimpangan perilaku seksual. Bebasnya akses internet yang menjadikan peserta didik berperilaku seksual aktif. Seperti menonton porno 53,08\%, berhubungan seks 9,90\%.

Sekolah merupakan sarana dan prasana berlangsungnya kegiatan belajar mengajar. Dalam kegiatan pembelajaran media merupakan salah satu hal yang penting dari semua proses kegiatan belajar mengajar. Media pembelajaran merupakan parantara atau pengantar pesan dari pengirim dan penerima pesan, media dapat berupa suatu bahan dan alat. Jenis-jenis media pembelajaran ada yang visual dan ada yang audio visual. Salah satu contoh media visual ialah poster. Siswa SMA lebih banyak menerima pembelajaran teori dari pada praktek

Berdasarkan studi pendahuluan di SMAN 8 Kota Jambi diketahui bahwa kurikulum yang dipakai pada mata pelajaran Biologi ialah kurikulum 2013 edisi revisi. Selain itu juga diketahui bahwa buku paket kurang membantu dalam membahas materi kesehatan reproduksi, hal ini terlihat dari penjelasan tentang kesehatan reproduksi masih sedikit. Poster kesehatan reproduksi belum ada di sekolah baik itu di mading sekolah, UKS (Usaha Kesehatan Sekolah) maupun dalam kegiatan pembelajaran. Menurut guru biologi pengetahuan dan informasi tentang kesehatan reproduksi sangat penting diberikan ke siswa-siswi usia remaja. tujuannya agar siswa-siswi usia remaja sekolah dapat terhindar dari penyimpangan seksual dan lebih perduli terhadap kesehatan reproduksinya.

Media poster digunakan sebagai perantara dan informasi secara tertulis didalamnya dapat dijadikan suplementasi dalam materi ajar sistem reproduksi, dengan sub pokok materi kesehatan reproduksi. Poster termasuk kedalam media pembelajaran visual. Dalam teori belajar media pembelajaran visual memiliki keterkaitan satu sama lain. Misalnya, yang pertama teori belajar Behaviorisme yang menekankan pada stimulus dan respon sehingga media visual (poster) dijadikan sebagai stimulus yang diaplikasikan dipandang memuaskan oleh siswa-siswi, maka responnya akan menguat. Kedua, yakni teori belajar kognitif yang menekankan pada pentingnya proses mental dalam belajar, misalnya, ketika siswa-siswi membaca media poster untuk mengenali makna yang tersirat didalamnya maka ia akan menggunakan mulutnya untuk mengucapkan kalimat yang terdapat dalam media 
poster tersebut (Dewi \& Budiana, 2018).

Kelebihan dari Poster dapat menimbulkan daya tarik tersendiri bagi pembaca, Bahasa yang digunakan mudah dimengerti dan tujuan nya jelas, Harga pembuatan cukup murah, Materi pada poster dapat mensuplementasi materi sistem reproduksi, Penggunaan poster tidak terbatas dalam ruang kelas saja namun bisa diletakkan pada mading dan UKS (Unit Kesehatan Sekolah). Penelitian ini bertujuan untuk mengembangkan poster kesehatan reproduksi berbasis pendidikan karakter menggunakan canva pada usia remaja sekolah di SMA

\section{METODE PENELITIAN}

Penelitian pengembangan poster untuk mengembangkan poster kesehatan reproduksi berbasis pendidikan karakter menggunakan canva pada usia remaja sekolah di SMA menggunakan model pengembangan ADDIE (Analiysis, Design, Development, Implementation, Evaluation). Hal ini dikarenakan setiap langkah atau prosedurnya jelas dari awal hingga akhir. Selain itu juga model ini terdapat tahap evaluasi sebagai salah satu tahapannya, dimana pada tahapan ini peneliti dapat melakukan revisi atau perbaikan berdasarkan saran dan komentar dari validator maupun subjek penelitian sehingga produk yang dikembangkan akan lebih baik Berikut tahapan pengembangan model ADDIE pada Gambar 1 berikut.

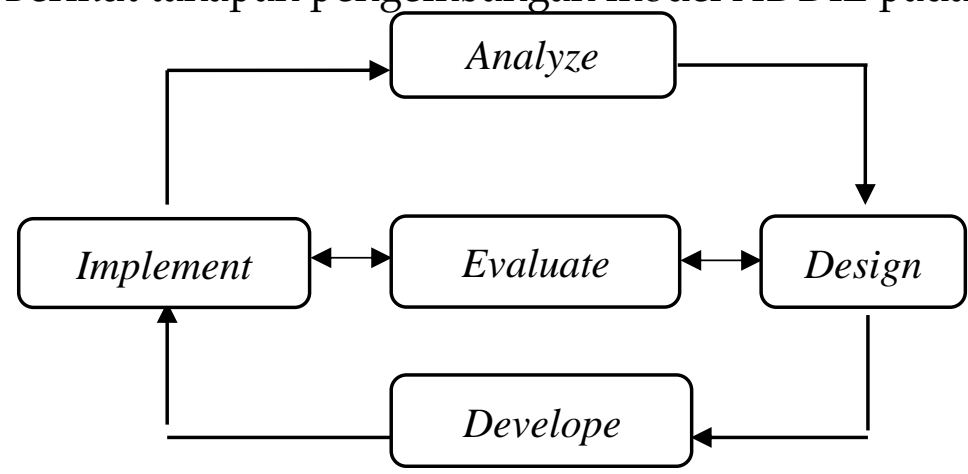

Gambar 1. Tahapan pengembangan model ADDIE (Lee \& Owens, 2004).

\section{Analisis (Analysis)}

Analisis kebutuhan

Berdasarkan observasi yang dilakukan di SMA Kota Jambi khususnya di SMAN 8 Kota Jambi diketahui bahwa sekolah menggunakan kurikulum 2013 revisi. Yang dikatahui bahwa kurikulum ini sangat mengedepankan aspek religi, kognitif, afektif, dan psikomotor. Sehingga siswa lebih aktif dan guru hanya sebagai fasilitator. Kemudian diketahui pula Penyuluhan tentang kesehatan remaja yang umumnya bekerja sama dengan pihak puskesmas terdekat dilakukan satu tahun sekali namun penyuluhan kesehatan reproduksi remaja sudah lama tidak dilakukan di SMAN 8 Kota Jambi.

Analisis materi

Pokok materi yang dituangkan pada media poster berbasis karakter ialah kesehatan organ reproduksi pada usia remaja sekolah. Diketahui dari buku ajar biologi kurikulum 13 edisi revisi yang digunakan siswa-siswi materi tentang kesehatan reproduksi belum ada. Kemudian dikatahui juga berdasarkan wawancara guru biologi SMAN 8 Kota Jambi belum ada media poster yang dapat mensuplementasi informasi kesehatan reproduksi baik di mading sekolah, dan dalam kegiatan pembelajaran khususnya kesehatan reproduksi. Serta penyuluhan tentang kesehatan reproduksi yang biasanya dilakukan oleh pihak puskesmas untuk 
beberapa tahun belakang belum ada.

\section{Desain (Design)}

Design (desain/ perancangan) Tahap desain ini, merumuskan tujuan pembelajaran yang SMART (Spesific, Measurable, Applicable, Realistic, and Timebound). Selanjutnya menyusun tes, dimana tes tersebut harus didasarkan pada tujuan pembelajaran yag telah dirumuskan tadi. Kemudian tentukanlah strategi pembelajaran media dan yang tepat harusnya seperti apa untuk mencapai tujuan tersebut. Selain itu, dipertimbangkan pula sumber- sumber pendukung lain, semisal sumber belajar yang relevan, lingkungan belajar yang seperti apa seharusnya, dan lain-lain (Trisiana \& Wartoyo, 2016).

Desain pengembangan media poster berbasis pendidikan karakter. pada materi kesehatan reproduksi untuk kelas XI SMA Negeri 8 Kota Jambi yaitu mendesain media poster, dalam mendesain poster peneliti menggunakan aplikasi Canva. Adapun cara membuat desain poster menggunakan aplikasi canva ini ialah sebagai berikut: (1) Buka aplikasi canva lalu klik desain poster baru, (2) Tentukan ukuran yang hendak digunakan, (3) Pilih template poster, atau desain poster yang cocok dengan pesan yang hendak disampaikan, (4) Sesuaikan poster dengan menambah gambar sendiri atau salah satu perpustakaan stok, ubah warna dan font untuk menyesuaikan kebutuhan, (5) Tambahkan text atau pesan yang hendak disampaikan, (6) Kemudian unduh, cetak atau bagikan poster yang telah diselesaikan. Lalu tahap selanjutnya setelah desain membuat prototype media poster berbasis pendidikan karakter pada materi kesehatan reproduksi.

\section{Pengembangan (Development)}

Pengembangan adalah proses mewujudkan blue-print alias desain tadi menjadi kenyataan. Artinya, jika dalam desain diperlukan suatu software berupa multimedia pembelajaran, maka multimedia tersebut harus dikembangkan. Satu langkah penting dalam tahap pengembangan adalah uji coba sebelum diimplementasikan. Tahap uji coba ini memang merupakan bagian dari salah satu langkah ADDIE, yaitu evaluasi (Trisiana \& Wartoyo, 2016).

Tahap pengembangan ini peneliti membutuhkan validator ahli materi dan validator ahli media. Dimana media perlu validasi oleh tim ahli sampai media poster yang dibuat benar-benar layak digunakan dalam kegiatan pembelajaran. Tahap pengembangan ini dimulai dari pembuatan produk awal yang dilakukan oleh peneliti, kemudian media tersebut diberikan oleh tim ahli supaya diberi penilaian, jika penilaian nya belum baik maka diminta saran perbaikan untuk merevisi ulang produk atau media poster. Tahap revisi dilakukan untuk dapat menyempurnakan produk atau media poster sehingga dapat digunakan. Jika setelah melalui tahap revisi dan penilaian tim ahli sudah baik maka media poster dapat dikatakan valid.

Selain validator ahli materi dan media pada tahap pengembangan ini diperlukan juga persepsi dari guru dan siswa. Persepsi diambil dengan cara pengisian angket persepsi, jika ada saran dari guru dan siswa maka poster perlu direvisi kembali sehingga didapatkan media yang layak diimplementasikan saat proses pembelajaran. Persepsi diambil dari satu guru biologi, enam remaja sekolah sebagai kelompok kecil, dan tiga puluh remaja sekolah sebagai kelompok besar. Remaja sekolah ditentukan oleh guru biologi dengan tingkat kognitif siswa yang bervariasi seperti tinggi, sedang, dan rendah. 


\section{Implementasi (Implementation)}

Implementasi adalah langkah nyata untuk menerapkan sistem pembelajaran yang sedang kita buat. Artinya, pada tahap ini semua yang telah dikembangkan diinstal atau diset sedemikian rupa sesuai dengan peran atau fungsinya agar bisa diimplementasikan. Implementasi atau penyampaian materi pembelajaran merupakan langkah keempat dari model desain sistem pembelajaran ADDIE (Trisiana \& Wartoyo, 2016). Tahap pelaksanaan ini juga merupakan evaluasi dari tahap perencanaan. Perlu dicatat apa saja yang meningkatkan pembelajaran dan apa saja yang menghambat pembelajaran trainee dari materi ajar yang telah dibuat. Hasil akhir dari tahap pelaksanaan adalah terjadinya proses pembelajaran yang efektif di dalam maupun di luar ruangan kelas (Isya, 2017).

Tahap implementasi dimana poster yang telah dibuat dan divalidasi diujicobakan oleh peneliti pada proses pembelajaran. Pada tahap ini dilakukan pretest-posttest untuk mengetahui efektivitas poster dalam uji coba satu kelas. Pretest diambil sebelum dimulainya pembelajaran. Hal ini digunakan untuk mengetahui seberapa jauh pengetahuan usia remaja sekolah tentang kesehatan reproduksi. Selanjutnya setelah dilakukan pembelajaran meggunakan media poster diambil nilai posttest sehingga didapatkan nilai perbandingan antara sebelum belajar dan sesudah belajar mengunakan poster tersebut.

\section{Evaluasi (Evaluation)}

Evaluasi yaitu proses untuk melihat apakah sistem pembelajaran yang sedang dibangun berhasil, sesuai dengan harapan awal atau tidak. Sebenarnya tahap evaluasi bisa terjadi pada setiap empat tahap di atas. Evaluasi yang terjadi pada setiap empat tahap di atas itu dinamakan evaluasi formatif, karena tujuannya untuk kebutuhan revisi. Evaluasi merupakan langkah terakhir dari model desain sistem pembelajaran ADDIE. Evaluasi adalah sebuah proses yang dilakukan untuk memberikan nilai terhadap program pembelajaran (Trisiana \& Wartoyo, 2016). Hasil akhir dari tahap ini adalah laporan evaluasi dan revisi dari masing-masing tahap untuk digunakan sebagai acuan revisi masing-masing tahapan serta feedback secara keseluruhan dari bahan ajar yang telah dibuat.

Evaluasi dibagi menjadi dua yakni evaluasi sumatif, dan evaluasi formatif. Evaluasi sumatif digunakan untuk mengetahui efektivitas tingkat kemampuan usia remaja sekolah terhadap pembelajaran yang telah dilakukan sedangkan evaluasi formatif digunakan untuk melakukan revisi produk dalam setiap tahapan proses pengembangan poster. Pada penelitian ini evaluasi sumatif menggunakan dengan desain one group pretest-postes. Desain ini terdapat pretes sebelum diberi perlakuan. Dengan begitu perlakuan dapat diketahui lebih akurat, karena dapat membandingkan dengan keadaan sebelum diberi perlakuan (Sugiyono, 2016).

Subjek implementasi penelitian poster kesehatan reproduksi adalah 30 siswa kelas XI SMA Negeri 8 Kota Jambi dan guru mata pelajaran biologi. Angket digunakan untuk mengumpulkan data tentang persepsi guru dan siswa dalam mengembangkan poster kesehatan reproduksi menggunakan canva. Validasi dilakukan dengan expert judgement yang melibatkan dosen ahli materi dan ahli media. Teknik analisis data yang digunakan saat Implementasi produk dengan desain One group pretest-posttest dengan analisis Normality gain. Perhitungan menggunakan gain score menurut Hake (1999) nilai awal dan nilai akhir dengan rumus:

$N$ gain score $=\frac{\text { skor posttest-pretest }}{\text { skor maksimum-pretest }}$ 
Variabel analisis kriteria penilaian pada Tabel 1 berikut.

Tabel 1. Kriteria penilaian

\begin{tabular}{cl}
\hline Batasan & Kategori \\
\hline$g \geq 0,7$ & Tinggi \\
$0,3 \leq g<0.7$ & Sedang \\
$g<0,3$ & Rendah \\
\hline
\end{tabular}

\section{HASIL DAN PEMBAHASAN}

Berdasarkan penelitian pengembangan didapatkan hasil berdasarkan tahapan addie yang pertama yakni tahap analisis yang telah dilakukan dengan cara melihat ketersediaan bahan ajar. diketahui bahwa buku ajar biologi kurikulum 13 edisi revisi yang digunakan siswa-siswi belum ada materi tentang kesehatan reproduksi. Berdasarkan data di Dinas Kesehatan Kota Jambi tahun 2018 jumlah remaja yang hamil di bawah umur 18 tahun sebanyak 141, merokok 1266, alkohol 24. Menurut data kekerasan terhadap perempuan dan anak (KTA) UPTD PPA Provinsi Jambi tahun 2019 terhitung sampai tanggal 11 Oktober sebanyak 108 Pelapor dengan data 36 anak yang mengalami kekerasan seksual. Untuk itu peneliti melakukan pengembangan poster kesehatan reproduksi.

Tahap selanjutnya yaitu tahap desain, peneliti memulai membuat produk awal poster kesehatan reproduksi dan melakukan FGD (Focus Group Discusion) bersama pembimbing. Setelah dibuat produk awal poster menggunakan aplikasi canva perlu divalidasi oleh tim ahli. Tim ahli dibutuhkan dua untuk melakukan validasi materi, validasi media terhadap poster yang dikembangkan.berikut hasil validasi dari ahli materi dapat dilihat pada Gambar 2.

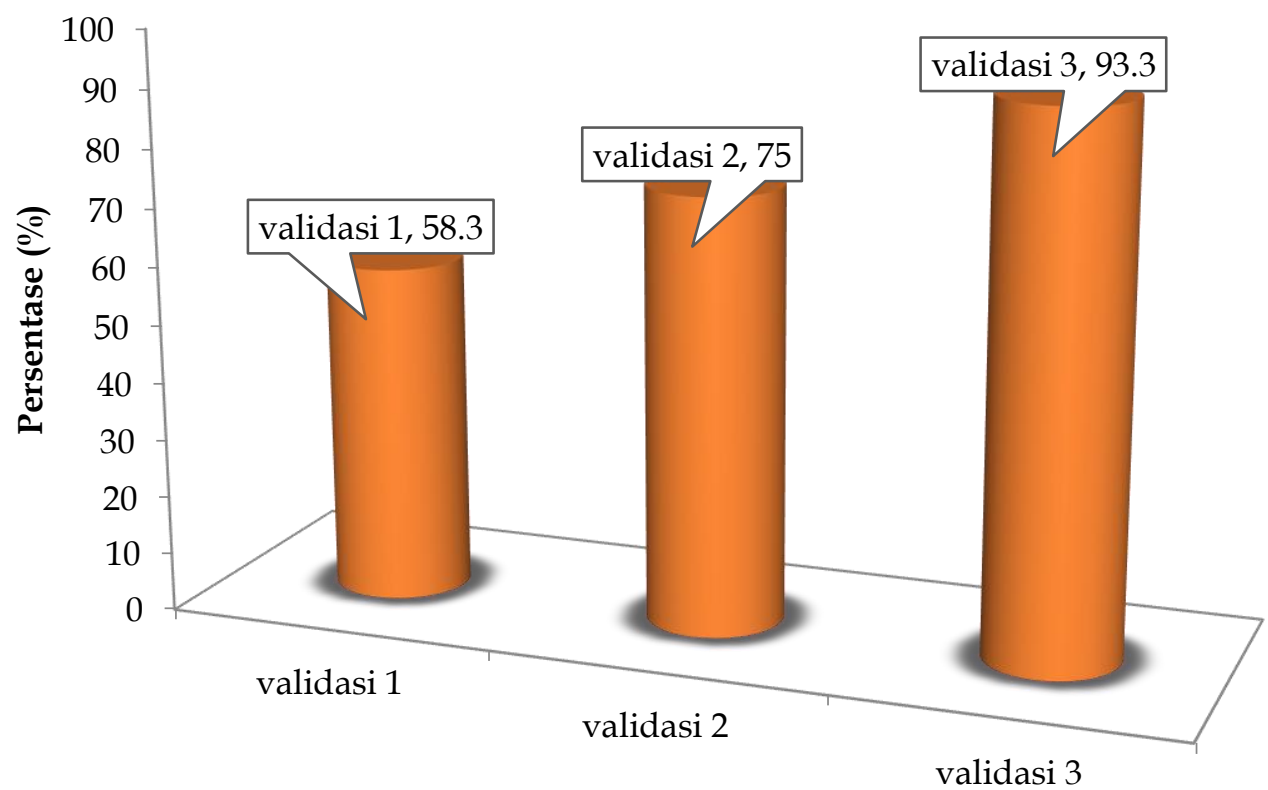

Gambar 2. Hasil validasi materi

Hasil dari validasi pertama oleh ahli materi diperoleh skor 35 atau $58.3 \%$ yang termasuk kategori "cukup baik". Namun, masih banyak kekurangan dalam semua aspek atau indicator. saran yang didapatkan dari validator ahli materi perlu direvisi diantaranya ialah kelengkapan lampiran seperti silabus, sumber materi kesehatan 
reproduksi yang digunakan, bahasa yang kurang sederhana. validasi kedua oleh ahli materi diperoleh skor 45 atau 75 \% yang termasuk kategori "sangat baik". Namun, masih ada kekurangan dalam aspek atau indicator bahasa. saran yang didapatkan dari validator ahli materi perlu direvisi diantaranya ialah sumber materi kesehatan reproduksi yang digunakan perlu ditambah, bahasa yang kurang sederhana. Hasil dari validasi ketiga oleh ahli materi diperoleh skor 56 atau $93.3 \%$ yang termasuk kategori "sangat baik". Pada validasi ketiga Validator ahli materi memberikan penilaian yang baik semua karena semua saran yang diperlukan sudah cukup terpenuhi dari aspek materi, maka selanjutnya yakni diperlukan validator media untuk menilai tampilan poster yang telah dibuat oleh peneliti.

Selanjutnya hasil validasi media yang didapatkan dari pengembangan poster kesehatan reproduksi dapat dilihat pada Gambar 3.

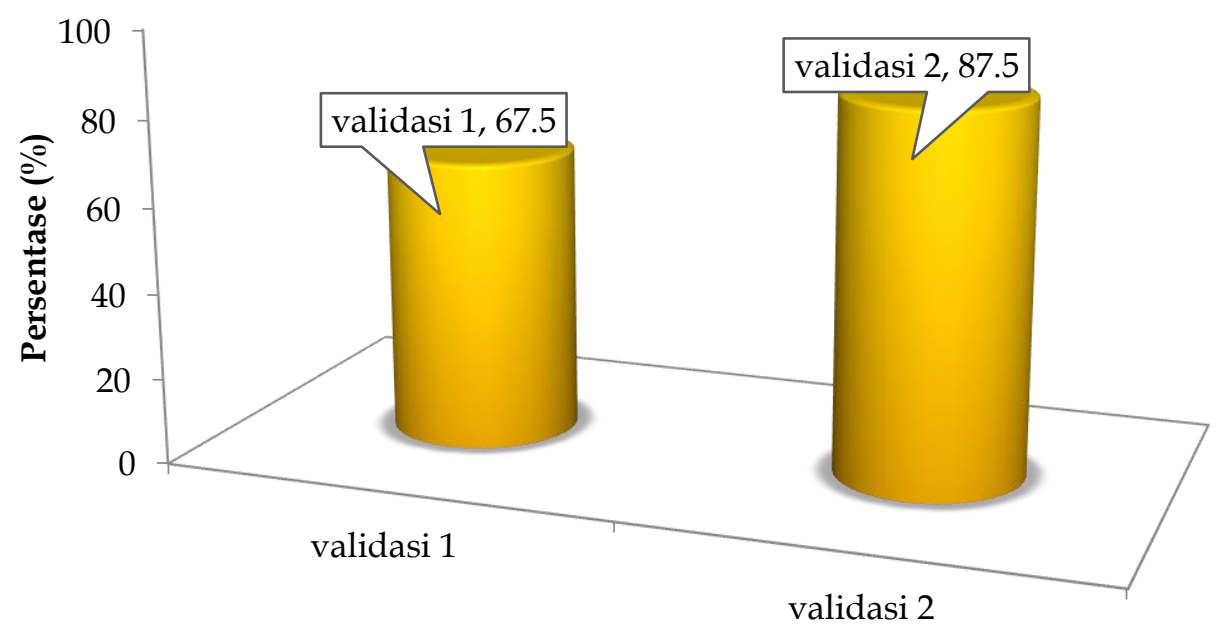

Gambar 3. Hasil validasi media

Hasil dari validasi pertama oleh ahli media diperoleh skor 27 atau $67.5 \%$ yang termasuk kategori "cukup baik". Namun, masih banyak kekurangan dalam semua aspek atau indicator. saran yang didapatkan dari validator ahli media perlu direvisi diantaranya ialah warna pada tulisan yang masih kurang tegas, ukuran huruf yang masih terlalu kecil, ukuran poster yang belum sesuai. Hasil dari validasi kedua oleh ahli media diperoleh skor 35 atau 87.5 \% yang termasuk kategori "sangat baik". Pada validasi kedua Validator ahli materi memberikan penilaian yang baik semua karena semua saran yang diperlukan sudah cukup terpenuhi dari aspek materi, maka tahap selanjutnya yakni diperlukan uji coba untuk mengetahui persepsi dari guru dan anak usia remaja sekolah sehingga didapatkan media yang layak dan dapat digunakan dalam proses pembelajaran di sekolah.

Kemudian setelah didapatkan hasil dari validator materi dan media, maka tahap selanjutnya mengetahui persepsi guru dan remaja sekolah. Hasil persepsi dapat dilihat pada Gambar 4. 


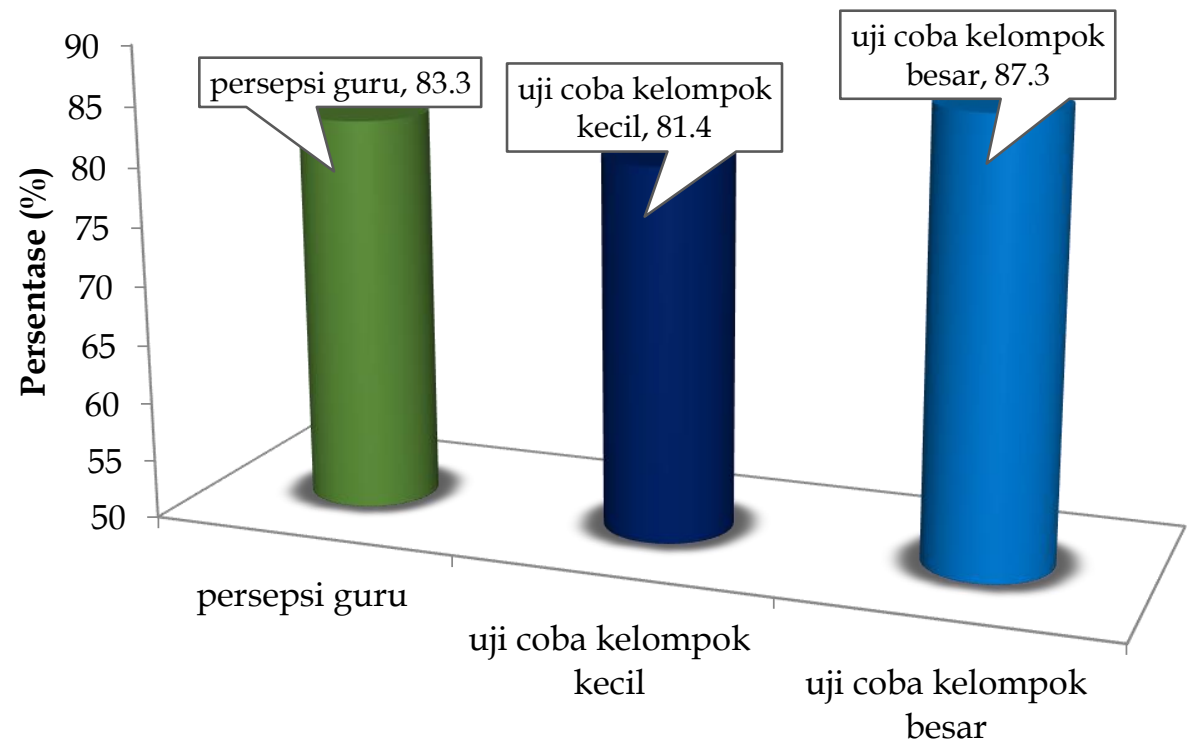

\section{Gambar 4. Hasil Persepsi}

Persepsi guru dan remaja sekolah didapatkan melalui penilaian angket. Persepsi guru diketahui media sudah baik dan efektif digunakan. Poster sudah sesuai dengan kebutuhan remaja sekolah, poster kesehatan reproduksi sudah menarik dengan Gambar dan warna-warna yang digunakan sesuai dengan tulisan, serta bahasa yang dignakan mudah dipahami oleh peserta didik. penilaian persepsi guru biologi terhadap poster sudah menunjukkan bahwa media termasuk dalan kriteria baik yakni $83.3 \%$. Hal ini sesuai dengan hasil penelitian yang dilakukan oleh Ernawati (2018) di mana poster yang dihasilkan sangat valid, poster sangat efektif digunakan, dan media poster dikategorikan sebagai media yang praktis untuk digunakan.

Persepsi remaja sekolah juga menunjukkan bahwa media sudah baik dan efektif hal ini diketahui dari angket persepsi yang telah diisi oleh remaja sekolah. Persepsi dari kelompok kecil diketahui bahwa poster dapat membantu remaja untuk lebih bertanggung jawab terhadap hak-hak reproduksi dan poster dapat membantu remaja dalam memahami kesehatan reproduksi, poster kesehatan reproduksi menarik, mudah dipahami, dan membatu menjadikan karakter diri lebih baik. Hasil yang didapatkan dari persepsi kelompok kecil yaitu $81.4 \%$ dengan kriteria poster baik. Tidak jauh berbeda dari hasil uji coba kelompok kecil persepsi remaja kelompok besar diketahui bahwa media termasuk dalam kriteria sangat baik dengan persentase $87.3 \%$.

Hasil pengembangan keseluruhan sesuai sesuai dengan penelitian Sumartono dan Astuti (2018) dalam pemanfaatan media poster menunjukkan efektif digunakan sebagai media komunikasi kesehatan karena tampilan fisiknya menarik, dibuat dengan menggunakan warna dan isi pesannya bermanfaat bagi pembacanya. Poster kesehatan reproduksi yang telah tervalidasi dan layak digunakan terlihat pada Gambar 5 berikut. 

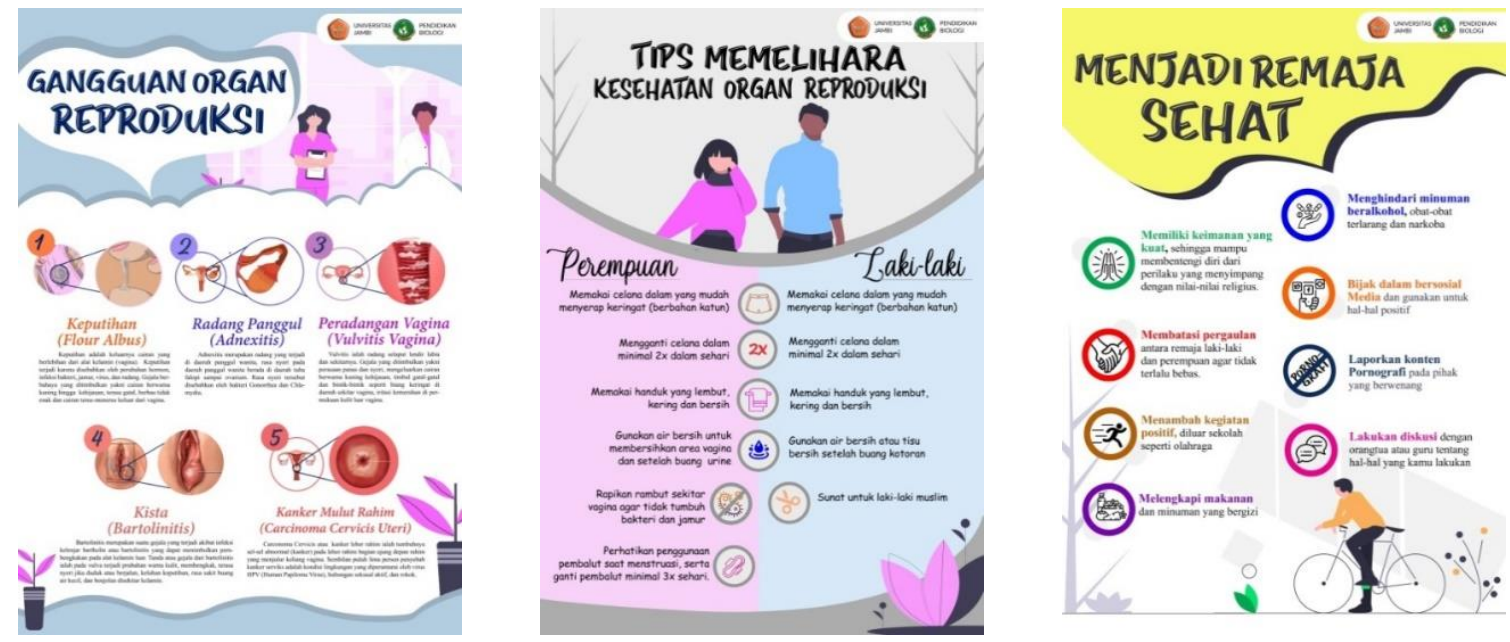

Gambar 5. Poster kesehatan reproduksi yang dihasilkan.

Tahap selanjutnya yaitu tahap implementasi dimana didapat hasil hasil pretest dan posttest dengan tujuan untuk mengetahui tingkat efektivitas poster dalam pembelajaran, hasil yang didapat dianalisis menggunakan Normality gain. Adapun hasil yang didapatkan yakni terlihat pada Tabel 2.

Tabel 2. Pemahaman kesehatan reproduksi

\begin{tabular}{ccccc}
\hline \multirow{2}{*}{$\mathrm{N}$} & \multicolumn{3}{c}{ Rata-rata } & \multirow{2}{*}{ Kriteria } \\
\cline { 2 - 4 } & Pretest & Posttest & n-gain & \\
\hline 30 & 32.13 & 76.53 & 0.65 & Sedang \\
\hline
\end{tabular}

Berdasarkan perhitungan $N$-gain diketahui bahwa hasil yang didapat usia remaja sekolah tentang kesehatan reproduksi rata-rata termasuk kedalam kriketeria sedang (0.65). Menurut Fahrurrozi, Hulyadi, dan Pahriah (2019) uji N-gain diperoleh skor rata-rata sebesar 0.6 dengan kategori sedang. Hal ini menunjukkan bahwa bahan ajar yang telah dikembangkan sangat layak untuk dilanjutkan ke tahap yang lebih luas dan efektif untuk menumbuhkan pemahaman siswa tentang kesehatan reproduksi. Penggunaan poster yang telah dikembangkan, pemahaman siswa-siswi mengenai kesehatan reproduksi meningkat sehingga poster efektif digunakan untuk menyampaikan pesan tentang pentingnya menjaga kesehatan reproduksi. Hal ini sesuai dengan penelitian sebelumnya yakni penelitian Situmorang, Muhibbuddin, dan Khairil (2015) menyatakan adanya peningkatan rata-rata hasil belajar siswa pada materi sistem ekskresi manusia maka pembelajaran dapat dikatakan pembelajaran sudah efektif. Berdasarkan penelitian sebelumnya yakni penelitian Sumartono dan Astuti (2018) dalam pemanfaatan media poster menunjukkan hasil yang baik. Hasil penelitian menunjukkan poster efektif digunakan sebagai media komunikasi kesehatan karena tampilan fisiknya menarik, dibuat dengan menggunakan warna dan isi pesannya bermanfaat bagi pembacanya.

Analisis terhadap nilai pretest dan posttes juga menunjukkan bahwa kemampuan siswa yang bermacam-macam. Beberapa siswa ada yang tidak terlalu mengalami peningkatan pemahaman tentang kesehatan reproduksi. Dari tiga puluh peserta didik yang mengalami peningkatan yang termasuk kriteria tinggi sebanyak dua belas dengan hasil posttest tertinggi yaitu sembilan puluh dua. Beberapa siswa yang termasuk dalam kriteria tinggi mampu menyerap informasi dengan cepat, seingga tidak perlu waktu yang lama untuk memahami materi yang disampaikan 
guru. Hal ini disebabkan oleh guru menyampaikan informasi dengan bahwa yang mudah dimengerti, media yang mendukung dan Gambar-Gambar yang menarik sehingga informasi yang didapatkan dapat terekam dalam ingatan peserta didik dengan cepat dan tepat. hal ini sesuai dengan penelitian yang dilakukan oleh (Ulya, Iskandar, \& Asih, 2017) Hasil yang didapat dari penelitian eksperimen ini ialah pendidikan kesehatan menggunakan media poster lebih efektif meningkatkan pengetahuan.

Beberapa siswa-siswi yang tidak terlalu mengalami peningkatan pemahaman tentang kesehatan reproduksi termasuk kriteria sedang dengan nilai posttest terendah yaitu lima puluh enam. Banyaknya peserta didik yang termasuk dalam kriteria sedang ialah delapan belas peserta didik dari tiga puluh total keseluruhan peserta didik. Kriteria sedang diartikan cukup meningkat pengetahuan tentang kesehatan reproduksi. Sehingga, masih tergolong baik karena dengan melihat poster ditambah dengan penjelasan yang mudah dipahami maka tidak sulit bagi siswa-siswi dalam memahami materi. Namun karena perbedaan kemampuan dan daya ingat peserta didik tidak dapat disama ratakan setiap siswa-siswi.

Perbedaan kemampuan pemahaman peserta didik berbeda-beda disebabkan oleh beberapa factor. Pada tahap implementasi berlangsung factor yang mempengaruhinya ialah kecepatan siswa dan siswi dalam memahami materi yang diberikan berbeda-beda, metode saat belajar siswa berbeda-beda terlebih saat implementasi guru (peneliti) menggunakan metode pembelajaran konvensional yaitu ceramah. hal ini lah alasan beberapa peserta didik tidak mengalami peningkatan yang cukup tinggi. Hal ini sesuai dengan hasil penelitian Ernawati (2018) menyatakan bahwa faktor yang mempengaruhi pengetahuan tentang kesehatan reproduksi remaja yakni jenis kelamin, jumlah sumber informasi dan pemanfaatan orang tua sebagai sumber informasi.

\section{KESIMPULAN}

Berdasarkan hasil pengembangan poster kesehatan reproduksi berbasis pendidikan karakter pada usia remaja sekolah diketahui bahwa poster kesehatan reproduksi layak digunakan. Hal ini diketahui dari hasil persentase penilaian guru terhadap poster pada angket yakni $83.3 \%$. Persepsi remaja sekolah terhadap poster yang telah dikembangkan sudah baik. Baik itu perepsi dari kelompok kecil maupun kelompok besar. hal ini diketahui dari persentase penilaian kelompok kecil yaitu 81.4\% dan kelompok besar yaitu 87.3\%. Maka poster kesehatan reproduksi dapat diterima dengan baik oleh guru dan remaja sekolah. Berdasarkan tahap implementasi one group pretest-posttes diketahui bahwa hasil belajar siswa-siswi meningkat saat menggunakan media poster sehingga poster sudah efektif digunakan saat kegiatan pembelajaran.

\section{SARAN}

Berdasarkan pengembangan produk. Poster ini hanya dapat digunakan setelah dicetak. Sehingga dapat disarankan agar pengembangan poster selanjutnya dapat diakses melalui smartphone, sehingga informasi yang diberikan cakupannya lebih luas.

\section{UCAPAN TERIMA KASIH}

Penelitian ini tidak menerima hibah khusus dari agensi pendanaan mana pun di sektor publik, komersial, atau nirlaba 


\section{DAFTAR PUSTAKA}

Dewi, P. K., \& Budiana, N. (2018). Media pembelajaran bahasa: aplikasi teori belajar dan strategi pengoptimalan pembelajaran. Malang: UB Press.

Efendi, F., \& Makhfudli. (2009). Keperawatan Kesehatan Komunitas teori dan praktik dalam keperawatan. Jakarta: Salemba Medika.

Ekawati, Y. N., Saputra, N. E., \& Periantalo, J. (2016). Risk behavior on students jambi. Jurnal Psikologi Jambi, 1(1), 19-28.

Ernawati, H. (2018). Pengetahuan kesehatan reproduksi remaja di daerah pedesaan 1. Indonesian Journal for Health Sciences, 02(01), 58-64.

Fahrurrozi, Hulyadi, \& Pahriah. (2019). Pengembangan Bahan Ajar Ikatan Kimia Model Inkuiri dengan Strategi Konflik Kognitif Terhadap Kemampuan Berpikir Kritis. Hydrogen: Jurrnal Kependidikan Kimia, 7(1), 12-24.

Hake, R. (1999). Analyzing Change/Gain Scores. Retrieved from https:// www.yumpu.com/en/document/read/18661327/analyzing-changegain-scores-indiana-university

Hartini. (2017). Perkembangan Fisik dan Bodu Image Remaja. Islamic Couseling, 1(02), 27-54.

Hasanah, H. (2016). Pemahaman kesehatan reproduksi bagi perempuan: Sebuah Strategi Mencegah Berbagai Resiko Masalah Reproduksi Remaja. SAWWA, 11(April), 229-252.

Irianto, K. (2015). Kesehatan Reproduksi (Reproductive Health) Teori Dan Praktikum. Bandung: Alfabeta.

Isya, muhammad andi. (2017). Pengembangan model pembelajaran instruksional design dengan model Addie mata. TA'DIBIA Jurnal Ilmiah Pendidikan Agama Islam, 7(1), 71-80.

Lee, W. W., \& Owens, D. L. (2004). Multimedia-based instructional Design, (2nd Ed). San Francisco: Pfeiffer.

Novendra, A. S., \& Puspitasari, N. (2017). Hubungan sikap pengendalian diri dalam penggunaan media jejaring sosial facebook dengan perilaku seksual pranikah remaja usia 15-19 tahun (studi dikelurahan kapasmadya baru kecamatan tambaksari kota surabaya). The Indonesian Journal of Public Health, 12(February), 85-96. https:/ / doi.org/10.20473/ijph.v12i1.2017.85-96

Situmorang, R. M., Muhibbuddin, \& Khairil. (2015). Rosdiana Meliana Situmorang. Jurnal EduBio Tropika, 3, 87-90.

Sugiyono. (2016). Metode Penelitian Pendidikan (Pendekatan Kuantitatif, Kualitatif, Dan RED). Bandung: Alfabeta.

Sumartono, \& Astuti, H. (2018). Penggunaan poster sebagai media komunikasi kesehatan. Komunikologi, 15, 8-14.

Trisiana, A., \& Wartoyo. (2016). Desain pengembangan model pembelajaran pendidikan kewarganegaraan melalui addie model untuk meningkatkan karakter mahasiswa di universitas slaet riyadi surakarta. PKn Progresif, 11(1).

Ulya, Z., Iskandar, A., \& Asih, F. T. (2017). Pengaruh Pendidikan Kesehatan dengan Media Poster Terhadap Pengetahuan Manajemen Hipertensi pada Penderita Hipertensi. Jurnal Keperawatan Soedirman, 12(1), 38-46.

Wahyuningtias, H., \& Wibisono, W. (2018). Hubungan penggunaan sosial media dan pengetahuan seks bebas pada siswa / siswi usia 17-18 tahun ( The Correlation Of Social Media Usage and free Sex Knowledge Of 17-18 Years Old Senior High School Students ). Jurnal Ners Dan Kebidanan, 5, 144-149. 
https:// doi.org/10.26699/jnk.v5i2.ART.p144

Wicaksana, E. J., Fitrihidajati, H., Si, M., Kuntjoro, S., Si, S., \& Si, M. (2015). Analisis kebutuhan pembelajaran berorientasi kecakapan hidup ( life skill) melalui pengembangan lembar kegiatan siswa ( lks ) untuk pembelajaran ipa di sekolah menengah atas, (November), 29-34. 